\title{
The Influence of Motivation and Work Experience on Employee Productivity
}

\author{
Imas Masriah \\ Pamulang University, South Tangerang, Banten, Indonesia \\ E-mail: lecturer02036@unpam.ac.id
}

(Received: December-2019; Reviewed: January-2020; Accepted: March-2020;

Avalaibel Online: March-2020; Published: March-2020)

cc (i) (8) This is an open access article distributed under the Creative Commons Attribution License EY NC CC-BY-NC-4.0 (2020 by author (https://creativecommons.org/licenses/by-nc/4.0/)

\begin{abstract}
This study aims to determine the effect of motivation and work experience on employee productivity at Starbuck Coffee at Graha Raya Bintaro. The method used is explanatory research with analysis techniques using statistical analysis with regression testing, correlation, determination and hypothesis testing. This study motivation significantly affects employee productivity by $51.3 \%$, and hypothesis testing obtained $\mathrm{t}$ count $>\mathrm{t}$ table or $(5,434>2,048)$. Work experience significantly affects employee productivity by $48.4 \%$; hypothesis testing is obtained $t$ count $>t$ table or $(5,122>2,048)$. Motivation and work experience simultaneously significantly affect employee productivity with the regression equation $\mathrm{Y}$ $=10.832+0.420 \mathrm{X} 1+0.300 \mathrm{X} 2$, and the influence contribution is $60.9 \%$, hypothesis testing is obtained $\mathrm{F}$ count> F table or $(21.018>2.960)$.
\end{abstract}

Keywords: Motivation; Work Experience; Employee Productivity.

\section{INTRODUCTION}

Companies need to manage human resources as best as possible in a company operating system. Because the key to a company's success is technical excellence and the availability of funds (Dong, 2015; Saggaf et al., 2017), through careful Human Resource planning, the workforce's work productivity can be increased. It can be realized through adjustments. Such as increased motivation and good work experience. Also, each employee can produce something that is directly related to the interests of the organization (Akib et al., 2019; Farida, 2017; Junus et al., 2016; Zainal et al., 2018).

Motivation and good work experience can also support the success of a company in achieving its goals (Niswaty et al., 2017; Saggaf et al., 2017; Syam et al., 2018). These two factors will create a high level of work productivity to support the company's success. Conversely, if the work productivity level decreases, it will prevent the company from 
achieving its goals. Therefore, the development of the quality of human resources is increasingly important. Companies that employ human resources want good results and benefits and can keep up with its changes and developments. Motivation and work experience are things that play an important role in increasing work effectiveness. Because people who have high motivation and work experience will try their best so that their work can succeed and possible will form an increase in work productivity (Rozi \& Sunarsi, 2020; Sutrisno \& Sunarsi, 2019).

Every company always wants the productivity of each employee to increase. To achieve this, the company must motivate all employees to achieve work performance and increase productivity. The addition of work experience that the employees have will provide a great relationship to achieve productivity. In making efforts to increase work productivity, Starbuck Cofee has established several efforts to motivate its employees' work. These efforts provide several work facilities that are very supportive in increasing productivity to all employees.

These facilities include work clothes, guaranteed meals, recreation, places of worship, sports rooms, holiday allowances, treatment rooms, insurance, salaries, bonuses, overtime pay, and more. All of that is provided by the company so that all employees work in it are truly guaranteed and at the same time can create a good motivation to achieve productivity levels. Education level and work experience also take precedence. Especially for the bookkeeping or office, at least it is limited to high school education. At the same time, the production department has a minimum junior high school education. However, in the employee recruitment process, companies prioritize prospective employees who already have work experience from similar companies. These are expected to create morale and high work performance in achieving a good level of productivity, as expected by the company.

\section{METHOD}

The population in this study amounted to 30 respondents Starbuck Cofee in Graha Raya Bintaro. This study's sampling technique was a saturated sample, where all members of the population were sampled. Thus the sample in this study amounted to 30 respondents. The type of research used is associative, where the aim is to determine the effect of the independent variable on the dependent variable either partially or simultaneously. The data are analyzing using instrument tests, classical assumption tests, regression, coefficient of determination, and hypothesis testing (Creswell \& Clark, 2017).

\section{RESULT AND DISCUSSION}

\section{Descriptive Analysis}

This test is used to determine the minimum and maximum score, the mean score, and each variable's standard deviation. The results are as follows:

Table 1

Results of Descriptive Statistics Analysis

Descriptive Statistics

\begin{tabular}{lcrrrr}
\hline & N & Minimum & Maximum & Mean & Std. Deviation \\
\hline Motivation (X1) & 30 & 32 & 49 & 38.93 & 4,118 \\
\hline Work Experience (X2) & 30 & 29 & 48 & 38.03 & 5,048 \\
\hline Employee productivity (Y) & 30 & 31 & 46 & 38.60 & 3,766 \\
\hline Valid N (listwise) & 30 & & & & \\
\hline
\end{tabular}


Motivation obtained a minimum variance of 32 and a maximum variance of 49-a mean score of 38.93 with a standard deviation of 4.188 . Work experience obtained a minimum variance of 29 and a maximum variance of 48 with a mean score of 38.03 with a standard deviation of 5.048. Employee productivity obtained a minimum variance of 31 and a maximum variance of 46 with a mean score of 38.60 with a standard deviation of 3.766 .

\section{Quantitative Analysis}

This analysis aims to determine the effect of the independent variable on the dependent variable. The test results are as follows:

\section{Multiple Linear Regression Analysis}

This regression test is intended to determine changes in the dependent variable if the independent variable changes. The test results are as follows:

\section{Table 2}

\section{Multiple Linear Regression Test Results}

\begin{tabular}{|c|c|c|c|c|c|}
\hline \multirow[b]{3}{*}{ Model } & \multicolumn{5}{|c|}{ Coefficients $^{\mathrm{a}}$} \\
\hline & $\begin{array}{r}\text { Unsta } \\
\text { Coe } \\
\end{array}$ & $\begin{array}{l}\text { dardized } \\
\text { icients }\end{array}$ & $\begin{array}{c}\text { Standardized } \\
\text { Coefficients }\end{array}$ & & \\
\hline & $\mathrm{B}$ & Std. Error & Beta & $\mathrm{t}$ & Sig. \\
\hline 1 (Constant) & 10,832 & 4,397 & & 2,464 & .020 \\
\hline Motivation (X1) & .420 & .143 & .460 & 2.939 & .007 \\
\hline Work Experience (X2) & .300 & .117 & .402 & 2,569 & .016 \\
\hline
\end{tabular}

a. Dependent Variable: Employee productivity (Y)

Based on the test results in the table above, the regression equation $\mathrm{Y}=10.832+$ $0.420 \mathrm{X} 1+0.300 \mathrm{X} 2$ is obtained. From this equation, it is explained as follows:

1. A constant of 10,832 means that if motivation and work experience are not available, there is an employee productivity value of 10,832 points.

2. The motivation regression coefficient of 0.420 is positive, meaning that every time there is an increase in motivation of 0.420 , the employee productivity will also increase by 0.420 points.

3. The work experience regression coefficient is 0.300 ; this figure is positive, meaning that every time there is an increase in Work Experience of 0.300 , the employee productivity will also increase by 0.300 points.

\section{Correlation Coefficient Analysis}

Correlation coefficient analysis is intended to determine the level of strength of the relationship between the independent variable and the dependent variable either partially or simultaneously. The test results are as follows: 
Table 3

Results of Testing the Motivation Correlation Coefficient of Employee Productivity.

\begin{tabular}{llr|r}
\hline \multicolumn{4}{c}{ Correlations $^{\mathbf{b}}$} \\
& \multicolumn{1}{c}{$\begin{array}{c}\text { Motivation } \\
(\mathrm{X} 1)\end{array}$} & $\begin{array}{c}\text { Employee } \\
\text { productivity (Y) }\end{array}$ \\
\hline Motivation (X1) & Pearson Correlation & 1 & $.716^{* *}$ \\
\cline { 2 - 4 } & Sig. (2-tailed) & & .000 \\
\hline $\begin{array}{l}\text { Employee productivity } \\
\text { (Y) }\end{array}$ & Pearson Correlation & $.716^{* *}$ & 1 \\
\cline { 2 - 4 } & Sig. (2-tailed) & .000 & \\
\hline
\end{tabular}

The test results obtained a correlation value of 0.716 means that motivation has a strong relationship with employee productivity.

Table 4

The Results of Testing the Correlation Coefficient of Work Experience on Employee Productivity.

\begin{tabular}{|c|c|c|c|}
\hline \multicolumn{4}{|c|}{ Correlations $^{\text {b }}$} \\
\hline & & $\begin{array}{c}\text { Work } \\
\text { Experience } \\
\text { (X2) }\end{array}$ & $\begin{array}{c}\text { Employee } \\
\text { productivity (Y) }\end{array}$ \\
\hline \multirow{2}{*}{$\begin{array}{l}\text { Work Experience } \\
\text { (X2) }\end{array}$} & Pearson Correlation & 1 & $.696 * *$ \\
\hline & Sig. (2-tailed) & & .000 \\
\hline \multirow{2}{*}{$\begin{array}{l}\text { Employee } \\
\text { productivity (Y) }\end{array}$} & Pearson Correlation & $.696 * *$ & 1 \\
\hline & Sig. (2-tailed) & .000 & \\
\hline
\end{tabular}

**. Correlation is significant at the 0.01 level (2-tailed).

b. Listwise $\mathrm{N}=86$

The test results obtained a correlation value of 0.696 means that work experience has a strong relationship with employee productivity.

Table 5

Results of the Simultaneous Correlation of Motivation and Work Experience Coefficient on Employee Productivity.

Model Summary

\begin{tabular}{lrrrrr}
\hline Model & R & R Square & Adjusted R Square & Std. Error of the Estimate \\
\hline 1 & $.780 \mathrm{a}$ & .609 & .580 & 2,441 \\
\hline
\end{tabular}

a. Predictors: (Constant), Work Experience (X2), Motivation (X1)

The test results obtained a correlation value of 0.780 means that motivation and work experience simultaneously have a strong relationship with employee productivity.

\section{Analysis of the coefficient of determination}

The coefficient of determination is intended to determine the independent variable's influence on the dependent variable either partially or simultaneously. The test results are as follows: 
Table 6

Results of Testing the Motivation Coefficient of Determination of Employee Productivity.

\begin{tabular}{lr|rrrr}
\multicolumn{6}{c}{ Model Summary } \\
\hline Model & R & R Square & Adjusted R Square & Std. Error of the Estimate \\
\hline 1 & $.716 \mathrm{a}$ & .513 & .496 & 2,674 \\
\hline
\end{tabular}

a. Predictors: (Constant), Motivation (X1)

Based on the test results, a determination value of 0.513 means that motivation has an influence contribution of $51.3 \%$ on employee productivity.

Table 7

Results of Testing the Coefficient of Determination of Work Experience on Employee Productivity.

Model Summary

\begin{tabular}{lrrrrr}
\hline Model & R & R Square & Adjusted R Square & Std. Error of the Estimate \\
\hline 1 & $.696 \mathrm{a}$ & .484 & .465 & 2,753 \\
\hline
\end{tabular}

a. Predictors: (Constant), Work Experience (X2)

Based on the test results, a determination value of 0.484 means that Work Experience has an influence contribution of $48.4 \%$ on employee productivity.

\section{Table 8}

Results of Testing the Coefficient of Determination of Motivation and Work Experience on Employee Productivity.

\begin{tabular}{lr|rrrr}
\multicolumn{6}{c}{ Model Summary } \\
\hline Model & R & R Square & Adjusted R Square & Std. Error of the Estimate \\
\hline 1 & $.780 \mathrm{a}$ & .609 & .580 & 2,441 \\
\hline
\end{tabular}

a. Predictors: (Constant), Work Experience (X2), Motivation (X1)

Based on the test results, the determination value is 0.609 , which means that motivation and work experience simultaneously influence $60.9 \%$ of employee productivity, while other factors influence the remaining $39.1 \%$.

\section{Hypothesis testing}

\section{Partial hypothesis test (t-test)}

Hypothesis testing with the t-test is used to determine which partial hypothesis is accepted. The first hypothesis: There is a significant influence between motivation on employee productivity. 
Table 9

Results of Motivation Hypothesis Test on Employee Productivity.

Coefficients $^{\mathrm{a}}$

\begin{tabular}{|c|c|c|c|c|c|c|}
\hline \multirow{2}{*}{\multicolumn{2}{|c|}{ Model }} & \multicolumn{2}{|c|}{$\begin{array}{l}\text { Unstandardized } \\
\text { Coefficients }\end{array}$} & $\begin{array}{c}\text { Standardized } \\
\text { Coefficients } \\
\end{array}$ & \multirow[b]{2}{*}{$\mathrm{t}$} & \multirow[b]{2}{*}{ Sig. } \\
\hline & & B & Std. Error & Beta & & \\
\hline \multirow[t]{2}{*}{1} & (Constant) & 13,097 & 4,719 & & 2,775 & .010 \\
\hline & Motivation (X1) & .655 & .121 & .716 & 5,434 & .000 \\
\hline
\end{tabular}

a. Dependent Variable: Employee productivity (Y)

Based on the table above's test results, the value of $t$ count $>t$ table or $(5,434>2,048)$ is obtained; thus, the first hypothesis that there is a significant effect between motivation on employee productivity is accepted.

Table 10

Hypothesis Test Results of Work Experience on Employee Productivity.

Coefficientsa

\begin{tabular}{|c|c|c|c|c|c|c|}
\hline \multirow{2}{*}{\multicolumn{2}{|c|}{ Model }} & \multicolumn{2}{|c|}{$\begin{array}{c}\text { Unstandardized } \\
\text { Coefficients }\end{array}$} & \multirow[t]{2}{*}{$\begin{array}{c}\text { Standardized } \\
\text { Coefficients }\end{array}$} & \multirow[b]{2}{*}{$\mathrm{t}$} & \multirow[b]{2}{*}{ Sig. } \\
\hline & & $\mathrm{B}$ & Std. Error & & & \\
\hline \multirow[t]{2}{*}{1} & (Constant) & 18,867 & 3,885 & & 4,856 & .000 \\
\hline & Work Experience (X2) & .519 & .101 & .696 & 5,122 & .000 \\
\hline
\end{tabular}

a. Dependent Variable: Bliblu (Y)

Based on the table above are test results, the $t$ count $>t$ table or $(5,122>2,048)$ is obtained; thus, the second hypothesis proposed a significant effect between work experience employee productivity is accepted.

\section{Simultaneous Hypothesis Test (Test F)}

Hypothesis testing with the F test is used to determine which simultaneous hypothesis is accepted. The third hypothesis There is a significant influence between motivation and work experience on employee productivity.

Table 11

Hypothesis Test Results on Motivation and Work Experience on Employee Productivity.

ANOVA $^{\mathrm{a}}$

\begin{tabular}{llrrrrr}
\hline \multirow{2}{*}{ Model } & & \multicolumn{3}{c}{ Mean } & & \\
\hline \multirow{2}{*}{1} & Regression of Squares & \multicolumn{1}{c}{ df } & Square & F & \multicolumn{1}{c}{ Sig. } \\
\cline { 2 - 7 } & Residual & 250,379 & 2 & 125,189 & 21,018 & $.000 \mathrm{~b}$ \\
\cline { 2 - 6 } & Total & 160,821 & 27 & 5,956 & & \\
\hline
\end{tabular}

Based on the table above's test results, the calculated $F$ value> F table or (21.018>2.960), the third hypothesis proposed a significant influence between motivation and work experience on employee productivity accepted. 


\section{Discussion}

\section{The Influence of Motivation on Employee Productivity}

Motivation has a significant effect on employee productivity with a correlation of 0.716 or has a strong relationship with an influential contribution of $51.3 \%$. Hypothesis testing obtained the value of $t$ count $>t$ table or $(5,434>2,048)$. Thus, the first hypothesis proposed a significant effect between motivation on employee productivity is accepted.

\section{The Effect of Work Experience on Employee Productivity}

Work experience has a significant effect on employee productivity with a correlation of 0.696 or has a strong relationship with an influential contribution of $48.4 \%$. Hypothesis testing obtained $t$ value $>t$ table or $(5,122>2,048)$. Thus, the second hypothesis proposed that there is a significant effect between work experience and employee productivity is accepted.

\section{The Influence of Motivation and Work Experience on Employee Productivity}

Motivation and work experience have a significant effect on employee productivity by obtaining the regression equation $\mathrm{Y}=10.832+0.420 \mathrm{X} 1+0.300 \mathrm{X} 2$, the correlation value is 0.780 or has a strong relationship with the contribution of the influence of $60.9 \%$ while other factors influence the remaining $39.1 \%$. Hypothesis testing obtained the value of $F$ count $>F$ table or $(21.018>2.960)$. Thus, the third hypothesis proposed that there is a significant effect between motivation and work experience on employee productivity is accepted.

\section{CONCLUSION}

Motivation has a significant effect on employee productivity with an influence contribution of $51.3 \%$. Hypothesis test obtained $t$ value> $t$ table or $(5,434>2,048)$. Work Experience has a significant effect on employee productivity with an influence contribution of $48.4 \%$. Hypothesis test obtained $\mathrm{t}$ value $>\mathrm{t}$ table or $(5,122>2,048)$. Motivation and work experience significantly affect employee productivity with an influence contribution of $60.9 \%$, while other factors influence the remaining $39.1 \%$. Hypothesis testing obtained the value of $F$ count> F table or $(21.018>2.960)$.

\section{REFERENCES}

Akib, H., Wagianto, E., Daraba, D., Farida, U., \& Niswaty, R. (2019). Shift-share analysis of the development of local competence as a basis for interregional cooperation in West Sulawesi Province, Indonesia. Journal of Legal, Ethical and Regulatory Issues, 22(1).

Creswell, J. W., \& Clark, V. L. P. (2017). Designing and conducting mixed methods research. Sage publications.

Dong, L. (2015). Public Administration Theories: Instrumental and Value Rationalities. Pagrave Macmillan. https://doi.org/10.1007/978-3-319-31816-5_2372-1

Farida, U. (2017). Analysis of Empowerment Program that was Implemented in Mamuju Regency East Sulawesi Indonesia. 149(Icest), 19-21.

Junus, D., Akib, H., Suratman, \& Tahir, H. (2016). The Recruitment system for civil servants from the perspective of developing organizational capacity in regional government. Social Sciences (Pakistan), 11(24). https://doi.org/10.3923/sscience.2016.5859.5863 


\section{8}

Pinisi Discretion Review

Volume 3, Issue 2, March, 2020 Page. 331- 338

Niswaty, R., Rusbiati, S., Jamaluddin, J., \& Salam, R. (2017). The Influence of Teacher's Reinforcement for Students Motivation. International Conference on Education, Science, Art and Technology, 148-152.

Rozi, A., \& Sunarsi, D. (2020). The Influence of Motivation and Work Experience on Employee Performance at PT. Yamaha Saka Motor in South Tangerang. Jurnal Office, 5(2), 65-74.

Saggaf, M. S., Salam, R., \& Wirawan, H. (2017). The Influence of Teacher's Pedagogic Competence on Learning Motivation of Student of Office Administration Expertise Package. 8th International Conference of Asian Association of Indigenous and Cultural Psychology (ICAAIP 2017).

Sutrisno, S., \& Sunarsi, D. (2019). The Effect of Work Motivation and Discipline on Employee Productivity at PT. Anugerah Agung in Jakarta. Jurnal Ad'ministrare, 6(2), 187-196.

Syam, A., Hasbiah, S., Yunus, M., \& Akib, H. (2018). Determinants of entrepreneurship motivation for students at educational institution and education personnel in Indonesia. Journal of Entrepreneurship Education, 21(2).

Zainal, H., Parinsi, W. K., Hasan, M., Said, F., \& Akib, H. (2018). The influence of strategic assets and market orientation to the performance of family business in Makassar City, Indonesia. Academy of Strategic Management Journal, 17(6). 